\title{
Faculty Perspectives on Synthesizing at the Graduate Level: ESL Doctoral Students' Challenges and Mentoring Strategies
}

\author{
Morayo Akinkugbe \\ Department of Foreign, Second and Multilingual Language Education, College of Education and Human \\ Ecology, The Ohio State University, Columbus, Ohio
}

\begin{abstract}
There are various ways that English as a Second Language (ESL) doctoral students' academic experiences in the US are influenced. For example, advisor-advisee relationships are significant ones that shape doctoral students experiences and one essential feature of this relationship is the guidance that students are provided with. Additionally, synthesizing which is another academic literacy adjustment for them is a frequently assigned task at universities in the US and is an important and demanding source-based writing assignment. If they are not well prepared, they could end up leaving their doctoral programs. In this article, I report findings from a qualitative study that focused on four faculty members' perspectives on the challenges that ESL doctoral students encounter when synthesizing candidacy exam essays and explored the techniques professors adopted in providing them with guidance during coursework. This study is part of a larger qualitative research that explores four ESL graduate students' experiences composing a doctoral candidacy exam essay. This study was informed by interviewing four participants at a large midwestern university, data was analyzed inductively and recursively. Findings revealed that faculty perceived ESL doctoral students had varying challenges depending on their diverse backgrounds and experiences. Furthermore, faculty provided different types of guidance to ESL doctoral students during course work to help them gain some experience before they wrote their candidacy exams. Broader implications of this study and future research directions were discussed.
\end{abstract}

Keywords: International students, ESL, second language literacy, writing from sources, higher education, candidacy exam, advisor-advisee relationships

DOI: $10.7176 / \mathrm{JEP} / 11-15-08$

Publication date:May $31^{\text {st }} 2020$

\section{Introduction}

A significant relationship that shapes doctoral students experiences during their entire graduate program are their advisor-advisee relationships (Knox, Pruitt \& Hill, 2006; Schlosser, Lyons, Talleyrand, Kim \& Johnson, 2011). One vital aspect of this relationship is the guidance that students are provided with which has been insufficiently explored in existing literature until recently (Knox, et al., 2011). Studies indicate that the guidance graduate ESL students receive when enrolled in course work varies because they are considered advanced students and are not really told what to do explicitly especially when writing and synthesizing (Angelova \& Riazantseva, 1999; Cho, 2009) multiple sources. In this study, synthesis is defined as "...a written discussion that draws on two or more sources. It follows that your ability to write syntheses depends on your ability to infer relationships among sourcesessays, articles and the like" (Behrens and Rosen, 1985, p. 27). One major way of evaluating whether doctoral students have learned from coursework and are able to proceed to "candidacy" or "All But Dissertation" (ABD) status is through their performance on the high-stakes Candidacy Examination (CE). CE which has also been referred to as qualification, preliminary or comprehensive exam is an essential stage of any doctoral program. This exam entails PhD students being assigned lengthier and more involved tasks that associated with synthesizing, like literature review and critical review papers. These assignments involve the use of multiple source texts and more comprehensive use of the types of synthesizing operations. After students pass this exam, they become doctoral candidates and are considered ready to conduct independent research (e.g. dissertation) as they advance to the phase of getting their doctoral degree (Burakgazi \& Yildirim, 2017; Furstenberg \& Nichols-Casebolt, 2001). Thus, if students are not given the proper guidance prior to the $\mathrm{CE}$, they might struggle more with acculturating into their doctoral programs.

Also, in the field of ESL research, the correspondence between doctoral students and faculty has been the most prominent in existing literature and studies have focused more on ESL graduate student perspectives on the difficulties they encounter in their graduate programs (Byers, Hwang, Angrove, Chandler, Christian, Dickerson, McAlister-Shields, Thompson, Denham \& Onwugbuzie, 2014; Casanave, 1992; Leki, 2007; Morita, 2001; Oliveira \& Lan, 2012). In fact, findings have revealed that faculty members have major influences in the acculturation of their doctoral students in different ways such as, being instructors, advisors or committee members for their dissertation and establishing a mentor and mentee relationship (Hirvela \& Yi, 2008; Lee \& Norton, 2003; Simpson \& Matsuda, 2008; Weidman \& Stein, 2003; Weidman, Twale \& Stein, 2001). These influences from faculty members have contributed in assisting doctoral students in learning, understanding and acquiring knowledge in participating effectively within the disciplinary community they are situated in. 


\section{Related Research on Graduate Advisor-Advisee Relationships and Academic Writing}

To contextualize this study, I discuss additional information and research on advisor-advisee relationships. Schlosser et al. $(2003,2011)$ defined an advisor as "the faculty member who has the greatest responsibility to helping guide the advisee through the graduate program"' (p. 179). Remarkably, Schlosser and Gelso (2001) discovered that doctoral programs utilize various terms to distinguish the individual who performs the roles and responsibilities of who an advisor is such as mentor, major professor, committee chair, and dissertation chair. However, according to Schlosser et al. (2011) descriptions and explanations sometimes do not point out the numerous responsibilities of the graduate advisor. During the progression of working together, the advisor frequently has to strike a balance between the advisee being a student and becoming a colleague (Gelso, 1979, 1993; Schlosser et al., 2011). This kind of intricacy, as suggested by Schlosser et al., (2011) could be reasons why there is insufficient empirical studies on the topic.

Previous literature reveals that the advisor-advisee working relationship is connected to student research selfefficacy, positive feelings concerning research, participation in professional activities (Schlosser et al., 2011; Schlosser \& Gelso, 2001). Thus, the advising connection, is essential for advisees and advisors and could influence "advisees' career development, professional functioning, and the general quality of the discipline" (Schlosser et al., 2011, p. 9). For example, Knox, Schlosser, Pruitt, Hill (2006) conducted a qualitative study that focused on interviewing 19 faculty members about their advising relationships. These faculty members were asked about the strategies they adopted in advising, and to elaborate on the positive or negative relationships they had with their advisees. Findings revealed that regarding advising, the faculty members considered themselves responsible for providing support, encouragement for their advisees and made their transition process through the doctoral program easier. Additionally, the advisors pointed out personal satisfaction as a pro for advising and lengthy time investment as the major con. Thus, on one hand appropriate advising relationships were reflected by showing reciprocal respect, effective communication, no disagreements, and similarity in career focus between advisor and advisee. On the other hand, challenging relationships were depicted by a no respect, communication difficulties, and an evading of conflict between both parties. In addition, advisees struggled frequently with research and the advisors often felt unproductive assisting them.

Building from the statements above, it is evident that advisor-advisee relationships are important because they shape doctoral students' experiences during their entire graduate program. However, this significant relationship has been insufficiently explored (Knox, Pruitt \& Hill, 2006; Schlosser, Lyons, Talleyrand, Kim \& Johnson, 2011) especially for student's synthesizing practices (Angelova \& Riazantseva, 1999, Belcher, 1994) in academic writing (e.g. candidacy exams). Synthesizing in this study is defined as "...a written discussion that draws on two or more sources" (Behrens \& Rosen,1985, p. 27). However, there has been limited scholarship on faculty's perspectives on doctoral students' challenges (Knox et al, 2006; Schlosser et al, 2011). Since international students attending US universities are on a constant increase (IIE 2018), US colleges have implemented stricter standards of writing expertise that affects ESL students directly (Angelova \& Riazantseva, 1999, p.1). They are evaluated with the same writing ability criteria used to assess their fellow domestic students and which presents them at a disadvantage. Moreover, regarding composing techniques and text creation, studies conducted in first language (L1) and second language (L2) writing reveals major distinctions between the two (Angelova \& Riazantseva, 1999; Kaplan 1966; Krapels, 1990; Silva, 1993; Morague e Silva, 1991; Connor, 1984; Connor, 1996).

Finally, since the larger portion of this research was conducted on ESL doctoral students' perspectives on composing an essay within the candidacy exam setting, therefore this research explores four professors (two from the college of education and two from foreign languages and literature) perspectives on the challenges that ESL doctoral students in their programs encounter when synthesizing exam essays and ways that they have mentored or provided guidance to advisees who struggle with the difficulty of graduate level training (e.g. dealing with course work and assignments) preceding the CE.

Consequently, the objectives of this study were to explore faculty members perspectives on the kinds of challenges that ESL doctoral students encounter when synthesizing candidacy exam essays; investigate the guidance that faculty provides to ESL doctoral students during course work and before taking their candidacy exam and to contribute to existing literature that has examined second language writing challenges and advisoradvisee relationship dynamics.

\section{Research Questions}

This study addressed the two research questions below:

1. What kinds of challenges do faculty perceive ESL doctoral students experience before and during the candidacy exam?

2. In what ways do faculty provide guidance to ESL doctoral students who struggle with synthesizing before taking the candidacy exam? 


\section{Participants}

The participants of this study were 4 professors at a large public Midwestern research university who were recruited via email invitation in Spring 2018. Their names (pseudonyms) are Dr. Mallory, Dr. Walsh from the (college of education) Dr. Gregory and Dr. Tennessee from the department of foreign languages and literature. Table 1 below provides more information on them:

Table 1. Participants' background information

\begin{tabular}{|l|l|l|l|l|l|}
\hline Names & Position & Gender & Department & Educational Background & $\begin{array}{l}\text { Years of } \\
\text { Experience } \\
\text { Advising }\end{array}$ \\
\hline $\begin{array}{l}\text { Dr. } \\
\text { Mallory }\end{array}$ & $\begin{array}{l}\text { Associate } \\
\text { Professor }\end{array}$ & Female & $\begin{array}{l}\text { College of } \\
\text { Education }\end{array}$ & $\begin{array}{l}\text { Francophone literature, } \\
\text { TESOL, applied linguistics } \\
\text { and anthropology }\end{array}$ & 12 years \\
\hline Dr. Walsh & Professor & Male & $\begin{array}{l}\text { College of } \\
\text { Education }\end{array}$ & $\begin{array}{l}\text { Psychology, cognition and } \\
\text { instruction }\end{array}$ & 19 years \\
\hline $\begin{array}{l}\text { Dr. } \\
\text { Gregory }\end{array}$ & Professor & Male & $\begin{array}{l}\text { Foreign } \\
\text { Languages and } \\
\text { Literature }\end{array}$ & $\begin{array}{l}\text { Linguistics, Spanish and } \\
\text { TESOL }\end{array}$ & 15 years \\
\hline $\begin{array}{l}\text { Dr. } \\
\text { Tennessee }\end{array}$ & Professor & Female & $\begin{array}{l}\text { Foreign } \\
\text { Languages and } \\
\text { Literature }\end{array}$ & $\begin{array}{l}\text { Applied linguistics and } \\
\text { German }\end{array}$ & 13 years \\
\hline
\end{tabular}

What we can see from table 1 above is that as at the time that this study was conducted, Dr. Mallory, Gregory and Tennessee have similar educational backgrounds (e.g. TESOL and applied linguistics) but major in different foreign languages (e.g. French, Spanish and German) with Dr. Walsh being the only one with a different educational background (e.g. Psychology). Additionally, these professors have at least over 10 of years of experience advising and working with domestic and international $\mathrm{PhD}$ students at their departments which suggests that they are very qualified in providing insights to the different challenges ESL doctoral students encounter when engaging in academic writing such as synthesizing and the guidance they have offered them during course work. Each interview conducted with the participants was approximately one and a half hours long and was conducted in English. The interviews elicited information about their educational background, reflections on their past experiences as doctoral students, experiences working with $\mathrm{PhD}$ students, goals for $\mathrm{PhD}$ students in their departments, definitions of synthesizing, perceptions they have of the challenges ESL doctoral students encounter and recommendations on various ways of assisting them.

\section{Research Methods}

Data Collection

This study was part of a larger qualitative study that explored reading-writing connections by investigating how ESL doctoral students approached synthesizing in one of their candidacy exam essays. Data was originally collected from four ESL doctoral students and four faculty members from a large midwestern university in the United States.

Prior to the data collection, the research design was created, decisions about the data collection procedures was made, methods, and research instruments were obtained (e.g. semi-structured interview questions with followup questions) for this study and (students' written products, stimulated recall interviews and reflections from doctoral student participants) in the larger study. The data reported here utilized mainly from one source. However, this research focused on the four faculty participants of this study.

\section{Data Analysis}

After collecting the data, the data analysis structure was compared with the research study's questions and objectives. Hence, data was analyzed inductively and recursively (Glaser \& Strauss, 1967; Merriam, 2009) throughout by examining interview transcripts and follow-up responses to provide a "thick description" (Merriam, p. 43) of the findings. In order to answer the research questions above, the data was analyzed in two ways. I was specifically interested in strategies that participants adopted in assisting advisees that they were assigned. The individual responses were analyzed first and were based on uncovering essential themes that were presented based on the data collected. The second part was a cross-case analysis conducted on all of the four participants responses where there was a comparison on their perspectives on the candidacy exam challenges international PhD students are confronted with and guidance they provided to struggling students during course work and leading to the candidacy exam. 


\section{Findings}

RQ1. What kinds of challenges do faculty perceive ESL doctoral students experience before and during the candidacy exam?

\section{Crisis of identity}

During the early stages of and transition into the doctoral program, PhD students sometimes have a period of uncertainty and confusion in which their sense of identity becomes insecure and they are unsure of who they are as scholars and graduate students. This leads them to question what they are doing or whether they should be engaging in a different career or field. This is because most doctoral students have a sense of self and know what type of research they want to engage in before they enroll into graduate school however, the demands and challenges of the program make them feel differently.

In describing his perception about this theme, Dr. Gregory said:

You can have somebody in the middle of dissertation project look at you and say I wanna be an airline pilot.

And I ask, "what does that have to do with what we're doing?" The student can say, "Because this is who

I'm becoming and I don't want to become this thing that I'm writing" (interview transcript, 3/21/18).

Dr. Gregory's comment revealed one of major challenges that ESL PhD students encounter especially when they are involved in academic writing that is different from the ones that they are exposed to in their home countries. This is because most doctoral students have a sense of self and know what type of research they want to engage in before they enroll into graduate school however, the demands, challenges of the program and diverse experiences they encounter make them feel differently.

\section{Struggling with synthesizing and its mental demands}

Reading and writing play an important role in the development of students' literacy skills because academic writing entails the use of source information. Thus, students' ability to write depends heavily on the quality of students' reading as well as what they gain from reading. Thus, integrating and analyzing multiple sources in papers to create new knowledge as writers is a very demanding and challenging task to accomplish. Dr. Tennessee summarized this challenge this way:

I think some of the difficulties some of the students that I've had is writing...I think writing is challenging and discipline is challenging... disciplining yourself that you write regularly. Also, some students don't have the skill yet to breakdown the project...they still appear they have this topic, but you need to break it down into smaller portions, work on these smaller portions, then come up and make the connection at some point. Some students have that ability or have developed the skills depending on their background. So I think maybe integrating literature review into their analysis and also writing the analysis that is not just a description of the data but really an analysis of the data is also demanding (interview transcript, 3/27/18).

What we see from Dr. Tennessee's remarks is that not only do these student writers struggle with the discipline of pacing themselves when writing, they also have challenges with integrating relevant literature and their data analysis together. It could be inferred from the statements above that academic writing is a multifaceted task that is mentally demanding.

\section{Insufficient knowledge about research methods to use}

Acculturating and transitioning to a new graduate level learning experience for international PhD students is a gradual process that takes some getting used to (Byers et. al, 2014). Some students enter into the PhD program not knowing what the research interests are and probably knowing just one kind of research method because they utilized it during their undergraduate or graduate degrees in their home countries. Once they are enrolled into a $\mathrm{PhD}$ program in the US, sometimes they are exposed to other research methods during course work. Therefore, for some students, they would rather continue with the one research method that they know without acquiring more knowledge on the other ones (e.g. quantitative, qualitative or mixed-methods) so that they can more options to explore from. This leads to confusion and indecisiveness for them on what research methods to adopt for course work or their pilot studies. Dr. Walsh elaborated more on this acculturation challenge by explaining:

One of challenges they face is being able to think about a research question before thinking about the research method. As you may know many students come to the program and they become familiar with certain research methodology be it a case study, be it ethnography or whatever. And then thinking about a research question that fits that research method whereas of course it should be the other way around and so that's a continual problem and I see that all the time. Students put in the cart before the horse in other words, thinking of the methodology before the question. A third challenge is I like my students to be very familiar both with qualitative and quantitative research methods and that's very challenging indeed usually there's one emphasis, one strength that they have but I want them to have some familiarity with both. And of course, thinking about study design, often when I talk to doctoral students and they have a good question and they have a methodology for addressing... they think they know what they're going to do and address it and I'll ask them so, what about your design? And they'll look at me as if I'm talking about architecture but what I mean is, 
"How are they going to design a study to address that question?" So, taking what they learned in a research methods course and actually transferring it to there is extremely difficult (interview transcript, 3/23/18).

Dr. Walsh's comment reveals a step-by-step process that ESL PhD students need to engage in before conducting research. However, they sometimes skip this process which leaves them confused and frustrated. These processes are: choosing a research topic, formulating research questions, designing the research method that fits the research question. According to him, when these students ignore these steps because they have insufficient knowledge about various research methods which becomes a huge challenge which delays their acculturation process. Dr. Mallory also supported Dr. Walsh's point by indicating that "I think what is interesting is some of the way we're preparing particularly in this department where mainly most of this program are methods courses, students have been put in the position of researcher early and some really struggle with that" (interview transcript, 3/9/18). In other words, another reason why some students struggle as research and with research methodology is because they are put into the researcher position too early especially without having the proper training or apprenticeship first.

\section{Enrolling in the doctoral program at varying stages of preparedness}

Sometimes students do not really understand the demands of doctoral studies and are shocked when they enroll into the program, are stressed and find it difficult to cope with the challenges because of their different backgrounds, experiences, writing skills and their level of mental readiness. Dr. Moore summarized her perspective on this challenge below:

Well people come in at varying states of preparedness for various things so it's safe to say becoming unprepared. Some people have this kind of preparation, some people have that kind of preparation so varying states of preparedness and I think one of the big challenges is the learning...moving.... well I'll say this as faculty, going past the candidacy exam from being a student to being a researcher. And what. It maybe that they're struggling with being a researcher using discourse data, it may be struggling with being in the position of researcher and that's not always clear what the problem is cos discourse analysis is not for everyone. Other things that are really difficult people coming with different levels of writing skills and that's huge, that's huge, huge (interview transcript, 3/9/18).

If students are coming from backgrounds where they are not exposed to a lot of writing, do not really understand how challenging the doctoral program is based on differences in the academic environment, have only conducted research in their home countries and are being put in the researcher position before they are even ready, it might be difficult for them to thrive in the program which could also lead to lack of self-confidence and anxiety.

\section{RQ2. In what ways do faculty provide guidance to ESL doctoral students who struggle with synthesizing before taking the candidacy exam? \\ Giving feedback}

According to Stenger (2014), feedback is an important part of learning that should be provided in a timely manner, constructive way and tailored to fit each student's needs as they are actively involved in the process. For instance, faculty had one-on-one meetings with their advisees to talk about their paper which they have found to be helpful because it assists students in having better ideas on their thought processes and research directions.

...We're gonna talk about this, you're gonna tell me what is it you're doing in this chapter? What are you doing in this section? What are you doing in this paragraph? What are you doing in this sentence? I mean that pretty often where I deal with people's writing is...you know... what is it you're setting out to do? Because in fact I think often people don't know what they're doing when they're writing. They're just writing and fill in the page and so fundamentally my feedback with my advisees is... what are you trying to do here? What's your goal? What's this section about? How does it fit the upper sections? How does fit your overarching goal? (interview transcript, 3/9/18).

Therefore, advisors have found it very helpful to talk to through their advisee's writing because it helps them process their thoughts better and they are able to brainstorm and think through their ideas which helps them in developing to be better writers producing sophisticated essays. Aside from giving verbal feedback, Dr. Gregory explained that kind of detailed feedback he gave to his students during coursework is the same thing he would provide them if they were writing a dissertation:

...I really wanted to change the structure of things is precisely because I feel like writing a paper that you get detailed up close feedback on from advisor is exactly parallel to what you do when you're writing dissertation and it's also very similar when you submit a research article and get reviewer feedback so I feel like the more authentic version of what it's like to write a dissertation, what it's like to write a research article is sort of achieved through having students write actual papers and not candidacy exams. Candidacy exams aren't irrelevant, it's not that you learn nothing about writing your dissertation from them, but I don't take your candidacy exam and kind of go through and this is critical (interview transcript, 3/21/18).

Hence, Dr. Gregory felt that helping students practice early on during course work and not waiting until their 
start writing their candidacy exams was essential in supporting and providing better guidance for students.

\section{Research Apprenticeship}

According to the Penn State College of Education website, Research Apprenticeship involves working with one faculty member on an established research project" (n.d) to provide opportunities for doctoral students to acquire first-hand experience on how to become a researcher. In other words, a novice will undergo training from an expert in the field in order to become one.

Often, I know the best way of helping students with their writing is I will often co-author papers for publication with students and they tell me that that's the most valuable experiences that they've had because....I've just written a paper with an international student from Korea and so she conceptualized it and wrote parts and then I will take those parts and then I will revise it and we'll go back but I will do a lot of work and they see me struggle, they see me rhetorically change things so it's clearer rhetorically. So, that learning experience co-writing with a professor is an incredibly valuable.....and I've seen that so many times (Dr. Walsh, interview transcript, 3/23/18).

Dr. Walsh's comment above points out a very effective way that has worked for him which is being able to encourage his advisee's research writing development by co-writing papers with them. The student learned about his writing process and how he struggled indicating that it was not an easy process for him either. Observing this process, will also boost his advisee's confidence in writing because they observe that the process is not an easy task to accomplish and it is okay to struggle before finding their balance again. Other ways that the participants of this study mentioned that they collaborate with their advisees on research projects as such as writing a paper, collecting data and analyzing it for a research study which offers them the opportunity of learning how to conduct research and practicing synthesizing by being thorough and comprehensive when writing publishable papers.

\section{Making accommodations and restructuring courses}

When faculty evaluate and reflect on how to be more accommodating with their courses because of their diverse students they have, what eventually happens is that they try to restructure their courses to meets the needs of their students. The faculty members of this study indicated that they made various changes (e.g. incorporating miniresearch projects into the class and writing final research reports about the projects) to their courses to better prepare students for candidacy exams, dissertations and scholarship. For instance, Dr. Mallory said she would incorporate mini research projects broken into parts for students to work on and then finally write a final research paper on a topic of their choice.

\section{Discussion and Implications}

Findings from the study indicate that the challenges ESL doctoral students grapple with when synthesizing candidacy exam essays is associated with the varying reading and writing experiences that they come with which is very different from the synthesizing conventions of the American academia which (Angelova \& Riazantseva, 1999, Belcher, 1994) also point out with their research findings. As Hirvela (2016) elucidates, "the ability to read signifies not only skill in reading for the comprehension of meaning, but also being able to use reading as a means of better understanding how to use texts" (p. 1). So, students learn about writing through reading while also recognizing information that can be utilized in their writing. Additionally, these students come into the program with diverse expectations of how they are supposed to succeed in their program but are eventually confused as to how to advance in the process because they are not told what to do explicitly and they have to navigate this experience, negotiate with faculty and figure it out themselves.

While the results from this study indicate that faculty members provide guidance to their students notwithstanding, these findings also reveal that ESL doctoral students might require more assistance and support from faculty members in order to successfully adjust to the demands of the PhD program and be successful in their future careers. Since international students make up a huge population in the educational sector in the US (IIE, 2018), this study contributes in creating awareness about the challenges that ESL doctoral students face when synthesizing multiple sources so as to find better ways of preparing incoming international $\mathrm{PhD}$ students in the future. Additionally, faculty might be required to modify course work assignments or tasks to assist and better prepare ESL students for the candidacy exam, dissertation and beyond as (Angelova \& Riazantseva, 1999; Schlosser, et al., 2011) suggested.

This study was also an avenue to shed more light on the importance of advisor and advisee relationships and how it could either make or mar an ESL doctoral student's journey or experience (Combs, 2011; Hirvela \& Yi, 2008) leaving them either empowered and with no confidence in their reading-writing ability. Finally, longitudinal studies could be conducted to monitor the progress of these students journey from their first year until their candidacy exam stage to trace their educational trajectory and explore their advisor and advisee relationships throughout this process as well. Also, since this study focused on four faculty members, another possible future research direction could be recruiting more faculty from different departments to acquire more knowledge about 
their perspectives on their advisor-advisee relationships, guidance they provide and its influence on their advisees' graduate school experiences. Findings from these future research directions will contribute immensely in assisting and preparing faculty and experts involved in knowing how to better serve ESL doctoral students.

\section{References}

Angelova, M. \& Riazantseva, A. (1999). "If you don't tell me, how can I know?": A case study of four international students learning to write the US way. Written Communication, 16 (4), 491-525. Retrieved from: https://doi.org/10.1177/0741088399016004004.

Belcher, D. (1994). The apprenticeship approach to advanced academic literacy: Graduate students and their mentors. English for Specific Purposes, 13 (1), 23-34.

Burakgazi, S. \& Yildirim, A. (2017). Journey into doctoral candidacy: A grounded theory study of doctoral qualification exam process. Croatian Journal of Education 19 (1), 63-92.

Byers, V. T., Smith, R. N., Hwang, E. , Angrove, K. E. , Chandler, J. I. , Christian, K. M. , Dickerson, S. H., McAlister-Shields, L., Thompson, S. P. , Denham, M. A. , Onwuegbuzie, A. J. (2014). Survival strategies: Doctoral Students' Perceptions of Challenges and Coping Methods. International Journal of Doctoral Studies, 9, 109-136. Retrieved from: http://ijds.org/Volume9/IJDSv9p109-136Byers0384.pdf

Casanave, C. P. (1992). Cultural diversity and socialization: A case study of a Hispanic woman in a doctoral program in sociology. In D. E. Murray (Ed.), Diversity as resource: Redefining cultural literacy (pp. 148182). Alexandria, VA: TESOL.

Cho, S. (2009). Disciplinary enculturation experiences of five East Asian doctoral students in US-based second language studies programmes. Asia Pacific Journal of Educationn, 29 (3), 295-310.

Connor, U. (1984). A study of cohesion and coherence in English as a second language students' writing. Papers in Linguistics, 17 (1-4), 301-316.

Connor, U. (1996). Contrastive rhetoric. Cambridge, MA: Cambridge University Press.

Combs, A. (2011). Mentors and muses. NeuroQuantology, 9 (3), 494-498.

Furstenberg, A. L., \& Nichols-Casebolt, A. (2001). Hurdle or Building Block. Journal of Teaching in Social Work, 21(1-2), 19-37. https://doi.org/10.1300/J067v21n01_03.

Gelso, C. J. (1979). Research in counseling: Methodological and professional issues. Counseling Psychologist, 8 , 7-35.

Gelso, C. J. (1993). On the making of a scientist-practitioner: A theory of research training in professional psychology. Professional Psychology: Research and Practice, 24, 468-476.

Glaser, B., \& Strauss, A. (1967). The Discovery of Grounded Theory: Strategies for Qualitative Research. Mill Valley, CA: Sociology Press.

Hirvela, A. \& Yi, Y. (2008). From expectations to empowerment: How a mentor and dissertation writer negotiated the intricacies of a qualitative results chapter. In C.P. Casanave \& X. Li (Eds.), Learning the literacy practices of graduate school: Insiders' reflection on academic enculturation (pp. 121-133). Ann Arbor, MI: University of Michigan Press.

Number of International Students in the United States Reaches New High of 1.09 Million. (2018, November 20). Retrieved from: https:/www.iie.org/Why-IIE/Announcements/2018/11/2018-11-13-Number-ofInternational-Students-Reaches-New-High.

Kaplan, R. B. (1966). Cultural thought patterns in intercultural education. Language Learning, 16, 1-20.

Knox, S., Scholsser, L., Pruitt, N., \& Hill, C. (2006). A qualitative examination of graduate advising relationships: The advisor perspective. The Counseling Psychologist, 34 (4), 489-518.

Krapels, (1990) The interaction of first and second language composing: Processes andrhetorics. Dissertation Abstracts International, 51 (12), 4045A.

Leki, I. (2007). Undergraduates in a second language: Challenges and complexities of academic literacy development. New York: Lawrence Erlbaum Associates.

Merriam (2009). Qualitative research: A guide to design and implementation. San Francisco, CA: Jossey-Bass.

Moragne e Silva, M. (1991). Cognitive, affective, social and cultural aspects of composing in first and second language: A case study of one adult writer. Dissertation Abstracts International, 52 (12), 2429A.

Morita, N. (2000). Discourse socialization through oral classroom activities in a TESL graduate program. TESOL Quarterly, 34, 279-310.

Oliveira, L., \& Lan, S-W. (2012). Preparing nonnative English-speaking (NNES) graduate students for teaching in higher education: A mentoring case study. Journal on Excellence in College Teaching, 23(3), 59-76.

Prior, P., \& Min, Y. (2008). The lived experience of graduate work and writing: From chronotopic laminations to everyday lamentations. In C.P. Casanave \& X. Li (Eds.), Learning the literacy practices of graduate school: Insiders' reflection on academic enculturation (pp. 230-245). Ann Arbor, MI: University of Michigan Press.

Schlosser, L. Z., Knox, S., Moskovitz, A. R., \& Hill, C. E. (2003). A qualitative study of the graduate advising 
relationship: The advisee perspective. Journal of Counseling Psychology, 50, 178-188.

Schlosser, L., Lyons, H., Talleyrand, R., Kim, B., \& Johnson, W. (2011). Advisor-advisee relationships in graduate training programs. Journal of Career Development, 38(1), 3-18.

Silva, T. (1993). Toward an understanding of the distinct nature of L2 writing: The ESL research and its implications. TESOL Quarterly, 27 (4), 657-677.

Stenger, M. (2014). 5 Research-Based Tips for Providing Students with Meaningful Feedback. Edutopia. Retrieved from: https://www.edutopia.org/blog/tips-providing-students-meaningful-feedback-mariannestenger.

Penn State college of education website. (n.d.). Research Apprenticeship. Retrieved from: https://ed.psu.edu/lps/ldt/research/research-apprenticeship 